ANAEROBIC COLUPNAR DENITRIFICATION OF HIGH NITRATE WASTEWATER 1

\author{
C. W. Francis and C. D. Malone ${ }^{2}$
}

\begin{abstract}
Anaerobic columns were used to test the effectiveness of biological denitrification of nitrate solutions ranging in concentration from 1 to $10 \mathrm{~kg} \mathrm{NO}{ }_{3} / \mathrm{m}^{3}$. Several sources of nitrate $\left(\mathrm{CaCNO}_{3}\right)_{2}, \mathrm{NaNO}_{3} \mathrm{NH}_{4} \mathrm{NO}_{3}$ and actual nitrate was:tes from a $\mathrm{UO}_{2}$ fuel fabrication plant) were evaluated as well as two packing media. The packing media were anthracite coal particles, whose $\in$ ffective diameter size ranged between 2 and $3 \mathrm{~mm}$, and polypropylene Rasichig rings $1.6 \times 1.6$ diameter. The anthracite coal proved to be the Detter packing media as excessive hydraulic short circuiting occurred in a $120 \times 15 \mathrm{~cm}$ diameter glass column packed with the polypropylene rings after 40 days operation. With anthracite coal, floatation of the bed occurred at flow rates $>0.80 \mathrm{~cm}^{3} / \mathrm{s}$. Tapered columns packed with anthracite coal eliminated the floatation problem, even at flow rates as high as $5 \mathrm{~cm}^{3} / \mathrm{s}$. Under optimum operating conditions the anthracite coal behaved as a fluidized bed. Maximum denitrification rates were 1.0-1.4 $\mathrm{g} \mathrm{NO}_{3} / \mathrm{m}^{3} / \mathrm{s}$ based on initial bed volume. Denitrification kinetics indicated that rates of denitrification became substrate inhibited at nitrate concentrations $>6.5 \mathrm{~kg} \mathrm{NO} 3 / \mathrm{m}^{3}$. Anaerobic columns packed with
\end{abstract}

${ }^{1}$ Research sponsored by U.S. Energy Research and Development Administration under contract with Union Carbide Corporation.

2 Senior staff scientist, Environmenta] Sciences Division, Oak Ridge National Laboratory, Oak Ridge, Tennessee 37830 , and graduate assistant, Civil Engineering Department, Tennessee Technological University, Cookeville, Tennessee 38501. 


\section{anthracite coal appear to $5:$ an effective method of nitrate disposal for nitrate rich wastewete: jeneratci at $\mathrm{LO}_{2}$ fuel fabrication plants}

- and fuel reprocessing facilities.

This report wot not Ne

spontsonest was prepared as an account of work

the [nitud States nor States Governmert. Neither

Resetrah and Development the United States Energy

their eniployees nor any of

subcontractors, or their any of their contractors, waranty, cupress their employees, makes any

liahility ur responsibility fored, or assumes any legal

or usefulrtiss of

process disclosed, or sepresents, apparatus, product of

infnige privately owned rights. 


\title{
ANAEROBIC COLUMNAR DENITRIFICATION OF HIGH NITRATE WASTEWATER'
}

C. W. Francis and C. D. Malone ${ }^{2}$

\author{
Environmental Sciences Division \\ Oak Ridge National Laboratory 3 \\ Oak Ridge, Tennessee 37830
}

${ }^{1}$ Publication No. _._, Environmental Sciences Division, ORNL.

2Present address: Civil Engineering Department, Tennessee Technological University, Cookeville, Tennessee 38501 .

${ }^{3}$ Operated by Union Carbide Corporation under contract with the U.S. Energy Research and Development Administration. 
ANAEROBIC COLUMNAR DENITRIFICATION OF HIGH $: T$ ITE HSTEWATER

In recent years, considerable effort has deci jirectid ioward the development of biological denitrification systems fir reloving nitrates from municipal and agricultural wastewater (Johnsis and schroepfer 1964; Smith et a1. 1972; McCarty 1969). In general, these systems are either anaerobic packed beds or continuous flo:i stirred reactors. Nitrate concentrations in municipal and agricultural lastchater seldom exceed $250 \mathrm{~g} \mathrm{NO}_{3} / \mathrm{m}^{3}$; thus, 1 ittle research has been conducted on the removal of nitrates from wastewaters contairing concentraticns in excess of $1000 \mathrm{~g} \mathrm{NO}_{3} / \mathrm{m}^{3}$.

A number of manufacturing operations, such as fertilizer and explosives production facilities, generate wastewater effluents containing concentrations of $\mathrm{NO}_{3}>1000 \mathrm{~g} / \mathrm{m}^{3}$. Our major concern is how to treat the large quantities of wastewater effluents containing high nitrate concentrations that are produced in nuclear fuel processing operations and uranium oxide fuel fabrication plants. Thus, the purpose of this paper is to present results of the biological denitrification of several sources of nitrate at influent concentrations exceeding $1000 \mathrm{~g} \mathrm{NO}_{3} / \mathrm{m}^{3}$ in anaerobic columns using two packing media. Another paper, to be published later (Francis and Malone 1975a), will deal with denitrification at similar nitrate concentrations in continuous flow stirred reactors. A comprehensive review evaluating the advantages and disadvantages of each engineering design, anaerobic columns and continuous flow stirred reactors, for various nitrate enriched wastewater effluents associated with the nuclear fuel cycle has been published elsewhere (Francis and Callahan 1975). 


\section{THEORY AND METHOD OF EXPRESSING DENITRIFICATION RATES}

Biological denitrification is the reduction by microorganisms of nitrate or nitrite to gaseous molecular nitrogen or oxides of nitrogen. Dissimilatony biological denitrification is nitrate reduction where nitrate serves as the terminal electron (hydrogen) acceptor in the oxidation of an organic substrate by a large number of facul tative anatrobic bacteria. It should not be confused with assimilatory denitrification which is the reduction of nitrate or nitrite to ammonia for synthesis of amino acids, amino sugars and nucleotides in anabol ic cell metabolism.

Biological de itrification can only occur under an anaerobic environment or at least a "reduced environment" where the redox potential is $<250 \mathrm{mV}$. Optimum denitrification occurs in the $\mathrm{pH}$ range from 7.5 tc 8.5. Two substrates must be available, nitrate and an energy source, usually a hydrocarbon which also supplies carbon for additional cell synthesis.

Assuming an adequate carbon source is available, nicrate removal rate is dependent on nitrate concentration and microbial cell concentratior. Anaerobic columnar units (conventionally called packed bed reactors) in which the influent nitrate stream is introduced at the bottom of the column encourage maximum microbial cell concentrations in denitrification reactors due to the large surface area provided by the packing matrix. As cell buildup in the column exceeds that washed from the reactor, the hydraul ic residence time in the column decreases at constant influent flowrates. Continued cell buildup eventually plugs the column unless 
preventative measures: such as backwashing or flushing, etc. are taken. As denitrification progresses, the void spaces become filled with $\mathrm{N}_{2}$ and $\mathrm{CO}_{2}$ rather than substrate. Thus, any hydraulic residence time based on initial void space is a maximum value and the real hydraul is residence times after prolonged operation of a column are likely to be factors 5 to 10 lower. In the following work, denitrification rates were not considered valid unless at least 10 hydraulic residence times, based on initial void space of the packing material, had elapsed. Valid denitrificat:on rates in anaerobic columns should include current hydraulic residence: times as well as microbial concentrations. This was done in the continuous flow stirred reactor work (Francis and Malone 1975a), but for the columnar studies determinations of such parameters were considered inpractical. For this reason, rates of denitrification are based on initial volume of packing medium in the following manner:

$$
R=\left(\Delta \mathrm{NO}_{3}\right)(W) / N
$$

where

$$
\begin{aligned}
\mathrm{R} & =\text { denitrification rate in } \mathrm{mg} \mathrm{NO}_{3} / \mathrm{m}^{3} / \mathrm{s}, \\
\Delta \mathrm{NO}_{3}= & \text { difference between inf luent and effluent } \mathrm{NO}_{3} \\
& \text { conceritration in } \mathrm{kg} \mathrm{NO} \mathrm{NO}_{3} / \mathrm{m}^{3}, \\
W= & \text { flow rate in } \mathrm{cm}^{3} / \mathrm{s}, \text { and } \\
\dot{V} & =\text { initic. volume of packing medium in } \mathrm{m}^{3} .
\end{aligned}
$$

\section{MATERIALS AND METHODS}

The packing media included anthracite coal particles and polypropylene Raschig rings. Both are available cormercially. The anthracite coal was obtained from the Shamoking Filter Co., Inc., 
Shamokin, Pennsylvania and is "filt-0-Cite Ho. 1.5 " which has an effective particle diameter betwion 2 and 3 nu. The paricicles are angular, irregularly shaped and have an average particle density of approximately $1.5 \mathrm{~kg} / \mathrm{m}^{3}$. Initial bed porosity after piacenent in the column was $30 \%$. The polypropylene Raschig rings, "Flexirings", were obtained from Koch Engineering Co., Wichita, Kansas. The rings are $1.6 \times 1.6 \mathrm{~cm}$ dianeter and have a geonetric surface of $3.2 \mathrm{~m}^{2} / \mathrm{m}^{3}$ and a free space of $92 \%$.

A11 reactors were seeded from a microbial stock culture obtained from soil. The original stock culture was obtained in the following manner. Approximately $10 \mathrm{~g}$ of a soil from an organic horizon of an Emory silt loam or the ORNL reservation were added to $8 \mathrm{dnl}^{3}$ of $\mathrm{Ca}\left(\mathrm{NO}_{3}\right)_{2}$ solution containing approximately $1000 \mathrm{~g} \mathrm{NO}_{3} / \mathrm{m}^{3}$ and $600 \mathrm{~g}$ $\mathrm{CH}_{3} \mathrm{OH} \mathrm{g} / \mathrm{m}^{3}$. Anaerobic conditions and occasional stirring every three to four days produced a healthy culture of denitrifiers after 10-20 days. Columnar units were seeded by recycling $80 \mathrm{dm}^{3}$ of $\mathrm{Ca}\left(\mathrm{NO}_{3}\right)_{2}$ solution containing approximately $1000 \mathrm{~g} \mathrm{NO}_{3} / \mathrm{m}^{3}, 600 \mathrm{~g} \mathrm{CH}_{3} \mathrm{OH} / \mathrm{m}^{3}$ and 2-3 $\mathrm{dm}^{3}$ of an active culture of denitrifiers. Recycling continued until a microbial population was established on the packing media; subsequently, nitrate feed containing $0.6 \mathrm{~g} \mathrm{CH}_{3} \mathrm{OH} / \mathrm{g} \mathrm{NO}$ was passed slowly $\left(0.17\right.$ to $\left.0.80 \mathrm{~cm}^{3} / \mathrm{s}\right)$ through the column. Influent solutions were made with spring water and in addition to the nitrate and carbon substrate containef the following in mol/liter: $3.2 \times 10^{-4} \mathrm{KH}_{2} \mathrm{PO}_{4}$, $7.7 \times 10^{-4} \mathrm{MgSO}_{4}, 2.75 \times 10^{-3} \mathrm{FeCl}_{3} \cdot 6 \mathrm{H}_{2} \mathrm{O}$, and $4.13 \times 10^{-7} \mathrm{NaMoO}_{4} \cdot 2 \mathrm{H}_{2} \mathrm{O}$.

Nitrate measurements were made with an Orion Nitrate Specific Electrode Mode1 92-07 connected to a Corning Model 110, digital, expanded scale pH meter. Interferences by nitrite were eliminated 
by complexing the nit:rite with sulfanilamide in $0.01 \mathrm{~N}_{2} \mathrm{SO}_{4}$ according to the procedure of 'rancis and Malone (1975b). Use of $0.01 \mathrm{~N} \mathrm{H}_{2} \mathrm{SO}_{4}$ acts as an ionic strength adjustor and eliminates any interferences by $\mathrm{HCO}_{3}^{-}$and $\mathrm{CO}_{3}^{-2}$. Nitrite concentrations were determined colorimetricaliy according to Bremner (1965) and $\mathrm{CH}_{3} \mathrm{OH}$ concentrations with a gas chromatograph.

Two columnar linits were used: the first, a glass column 120 by $15 \mathrm{~cm}$ diameter, and the second, a tapered column made of "plexiglas", as illustrated in Fig. 1.

\section{RESULTS AND DISCUSSION}

\section{Anthracite Coal Packing - Glass Column}

Nitrate Sourise - Solutions made from three nitrate saits $\left(\mathrm{Ca}\left(\mathrm{NO}_{3}\right)_{2}\right.$, $\mathrm{NaNO}_{3}$, and $\left.\mathrm{NH}_{4} \mathrm{NO}_{3}\right)$ and actual nitrate wastes from an $\mathrm{UO}_{2}$ fuel fabrication plant were used as influent solutions in the columnar denitrification studies. As reparted earlier (Auerbach et al. 1974), the use of $\mathrm{Ca}\left(\mathrm{NO}_{3}\right)_{2}$ results in the formation of $\mathrm{CaCO}_{3}$ which causes high head losses (> $90 \mathrm{kPa}$ ) and eventuaily plugs the colunn. Calcium carbonate is the secondary reaction product formed from $\mathrm{Ca}$ and $\mathrm{CO}_{2}$ produced by the denitrification reaction. Continuous flow stirred reactors appear to be a more realistic engineering desigr: to denitrify nitrate wastes where the dominant complementary cations arı Ca or Al (Francis and Callahan 1975).

With influent solutions made from $\mathrm{NaNO}_{3}$ or $\mathrm{NH}_{4} \mathrm{NO}_{3}$ no insoluble carbonate compounds are formed which cause significant head losses. However, effluent $\mathrm{pH}$ values are considerably higher with $\mathrm{NaNO}_{3}$ and $\mathrm{NH}_{4} \mathrm{NO}_{3}$ than with $\mathrm{Ca}\left(\mathrm{NO}_{3}\right)_{2}$ (Table 1 ). The major difference in the denitrification of solutions containing $\mathrm{NaNO}_{3}$ and $\mathrm{NH}_{4} \mathrm{NO}_{3}$ is that rather high 


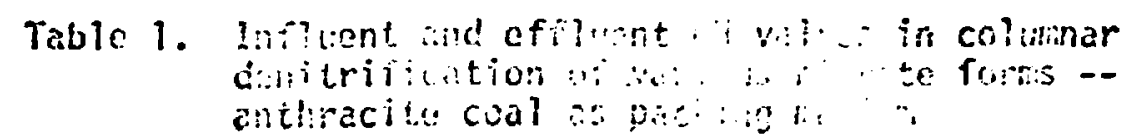

\begin{tabular}{|c|c|c|c|}
\hline Mitrate Form & Intinge & - & 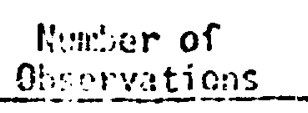 \\
\hline $\mathrm{Ca}\left(\mathrm{NO}_{3}\right)_{2}$ & $7.15 \pm 0.09^{1}$ & $7.6 \pm 0$ & 8 \\
\hline $\mathrm{NaHO}_{3} \mathrm{C}$ & $7.46 \pm 0.75$ & $3.5 \pm 0.1$ & 20 \\
\hline $\mathrm{NH}_{4} \mathrm{NO}_{3}$ & $6.86 \pm 0.09$ & $8.2 \pm 0.10$ & 13 \\
\hline $\mathrm{UO}_{2}$ Nitiate Wastes & $6.93 \pm 0.13$ & $8.23 \pm 0.1$. & 10 \\
\hline
\end{tabular}

'Standard deviation 
concentrations of nitrite (as great as $1000 \mathrm{~g} \mathrm{NO}_{2} / \mathrm{n}^{3}$ ) accumulate in the effluent of $\mathrm{NaNO}_{3}$ feed solutions (Table 2). On the other hand, micx inum concentrations of nitrite in the effluent of $\mathrm{NH}_{4} \mathrm{NHO}_{3}$ solutions did not exceed $10 \mathrm{~g} \mathrm{NO}_{2} / \mathrm{m}^{3}$ at any time during the study. A similar observation was made in the stirred reactor work. The addition of a small arount of amnonium $\left(10-15 \mathrm{~g} / \mathrm{m}^{3}\right)$ to $\mathrm{NaNO}_{3}$ influent solutions did not lower the nitrite accumulation, indicating the accumulation of nitrite is due to the levels of Na rather than any possible ammonium nutrient deficiencies.

Denitrification rates with solutions containing $\mathrm{Nr}_{4} \mathrm{NO}_{3}$ appear to be greater than those containing $\mathrm{NaNO}_{3}$ ( $\mathrm{Table}_{2}$ ). For example, the average denitrification rate with influent solutions containing $\mathrm{NaNO}_{3}$ was $245 \mathrm{mg} \mathrm{NO} / \mathrm{m}^{3} / \mathrm{s}$ while influents containing $\mathrm{NH}_{4} \mathrm{NO}_{3}$ averaged $326 \mathrm{mg} \mathrm{NO} / \mathrm{m}^{3} / \mathrm{s}$. This indicates that denitrification of influent solutions containing $\mathrm{NH}_{4} \mathrm{NO}_{3}$ is approximately $35 \%$ faster than for solutions containing $\mathrm{NaNO}_{3}$. This interpretation may be misleading if denitrification proceeds according to îrst order kinetics because the average concentration of nitrate in $\mathrm{NH}_{4} \mathrm{NO}_{3}$ influents $\left(11.8 \mathrm{~kg} \mathrm{NO} 3 / \mathrm{m}^{3}\right)$ was nearly twice the average nitrate concentration in $\mathrm{NaNO}_{3}$ influents $\left(6.5 \mathrm{~kg} \mathrm{NO} / \mathrm{m}^{3}\right)$. In addition, influents containing $\mathrm{NH}_{4} \mathrm{NO}_{3}$ followed those containing $\mathrm{NaNO}_{3}$ which introduces the possibility that a higher microbial population was present in the colurin for the $\mathrm{NH}_{4} \mathrm{NO}_{3}$ data. A more realistic comparison between denitrification rates can be made (if denitrification follows first order kinetics) by using Michael is and Menten relationships in the form of Lineweaver-Burk plots based on nitrate substrate concentrations. This subject is addressed in 


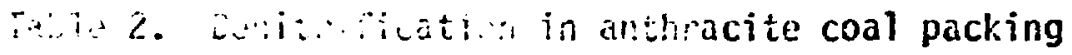

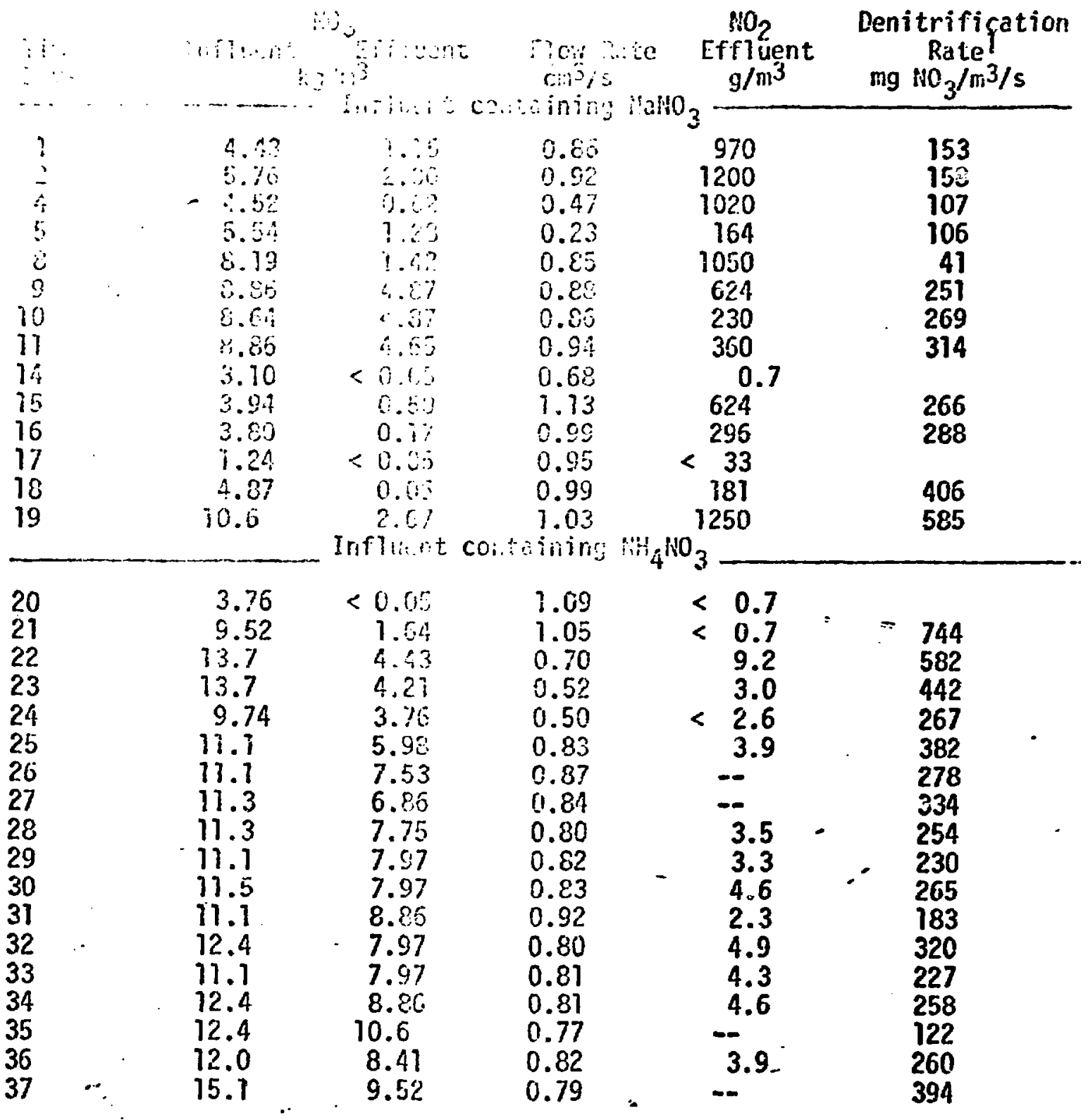

'Denitrification rate based on initial volume of packing medium, $11.12 \mathrm{dm}^{3}$, in a $120 \times 15 \mathrm{~cm}$ diameter glass columin. For influents containing $\mathrm{NaNO}_{3}$, rates were correrted for $\mathrm{NO}_{2}$ accumulation. 
another section. Denitrification rates determined in such a manner revealed little difference between maxillum denitrification rate $\left(R_{\max }\right)$ using $\mathrm{NaNO}_{3}$ influents $\left(R_{\max }=307 \mathrm{mg} \mathrm{NO}_{3} / \mathrm{m}^{3} / \mathrm{s}\right)$ and those containing $\mathrm{NH}_{4} \mathrm{NO}_{3}\left(\mathrm{R}_{\max }=351 \mathrm{ng} \mathrm{NO} / \mathrm{N}^{3} / \mathrm{s}\right.$. Thus, maximum denitrification rates calculated in this nanner are approximately $14 \%$ higher for influents containing $\mathrm{HH}_{4} \mathrm{NO}_{3}$ than for influents containing $\mathrm{NaNO}_{3}$. However, this may not even be statistically different. The major difference in the denitrification of solutions containing the two salts is not in the rate of denitrificition but rather in the concentration of the intermediate product, nitrite.

\section{Anthracite Coal Packing - Tapered Column}

Columns packed with anthracite coal appear to be a highly effective method for denitrifying high nitrate wastes. However, in the $120 \times 15 \mathrm{~cm}$ diameter column, floatation of the bed occurs at flow rates $>0.80 \mathrm{~cm}^{3} / \mathrm{s}$. Continued operation results in compaction of the bed against the top of the column which causes high head losses (>50 kPa). Floating of the anthracite bed is caused by the low density $\left(1.5 \mathrm{~kg} / \mathrm{m}^{3}\right)$ of the anthracite, large microbial growth on coal surfaces, and high producticn of $\mathrm{N}_{2}$. Use of the same anthracite coal in a tapered column alleviates compaction of the bed at the top of the column, even at flow rates of $5 \mathrm{~cm}^{3} / \mathrm{s}$, and under optimum operating conditions takes on many properties of a fluidized bed.

Denitrification kinetics indicate that rates of denitrification become nitrate substrate inhibited at nitrate concentrations $>6.5 \mathrm{~kg}$ $\mathrm{NO}_{3} / \mathrm{m}^{3}$. Thus, greater denitrification should be obtained in tapered columns than in conventional columns because greater quantities of 
nitrate can be delivered to the unit at influent nitrate concentrations which do not inhibit denitrification, viz., a greater fraction of the microbial enzyme can be maintained in the active form at influent concentrations of $5.0 \mathrm{~kg} \mathrm{NO} / \mathrm{m}^{3}$ and a flow rate of $5 \mathrm{~cm}^{3} / \mathrm{s}$ than at an influent concentration of $31 \mathrm{~kg} \mathrm{NO}_{3} / \mathrm{m}^{3}$ at $0.8 \mathrm{~cm}^{3} / \mathrm{s}$.

The column made of "Plexiglas" and tapered 0.23 rad deg outwardly (Fig. 1) was filled with $32.5 \mathrm{dm}^{3}$ of the same anthracite coal used in the previously described columnar studies. The column was seeded with an active denitrifying culture in the manner previously described, and an influent of $\mathrm{NH}_{4} \mathrm{NO}_{3}$ containing approximately $1 \mathrm{~kg} \mathrm{NO} / \mathrm{m}^{3}$ with $0.6 \mathrm{~kg} \mathrm{CH} \mathrm{CH}_{3} \mathrm{OH} \mathrm{m}^{3}$ was fed to the unit for three weeks before the denitrification data presented in Fig. 2 and Table 3 were collected. Visual observations revealed that the microbial growth was predominantly located in the lower one-third of the column indicating that an equilibrium microbial biomass had not been attained over the entire bed. Yet, the denitrification rate of $511 \mathrm{mg} \mathrm{NO} / \mathrm{m}^{3} / \mathrm{s}$ observed the first day of measurement (Table 3) was considerably higher than the average observed rate $\left(332 \mathrm{mg} \mathrm{NO} / \mathrm{m}^{3} / \mathrm{s}\right)$ obtained with $\mathrm{NH}_{4} \mathrm{NO}_{3}$ in the $120 \times 15 \mathrm{~cm}$ diameter column.

\section{Influence of Nitrate and Carbon Sources, Bed Expansion and Time -} Dentrification performance in the tapered column over a 41 day interval is illustrated in Fig. 2. On the fifth day, an influent containing 11.1 $\mathrm{kg} \mathrm{NO} \mathrm{N}_{3} / \mathrm{m}^{3}$ as $\mathrm{NH}_{4} \mathrm{NO}^{3}$ and acetic acid (neutralized with $\mathrm{NaOH}$ ) equivalent in terms of carbon to $0.6 \mathrm{~g} \mathrm{CH}_{3} \mathrm{OH} / \mathrm{g} \mathrm{NO}$ was fed to the unit at $3.73 \mathrm{~cm}^{3} / \mathrm{s}$; influent $\mathrm{pH}$ was 7.35. The following day nitrate analyses of the influent and effluent, and the observation that there was no difference between the teisperature of the two streams, indicated that denitrification had ceased. 


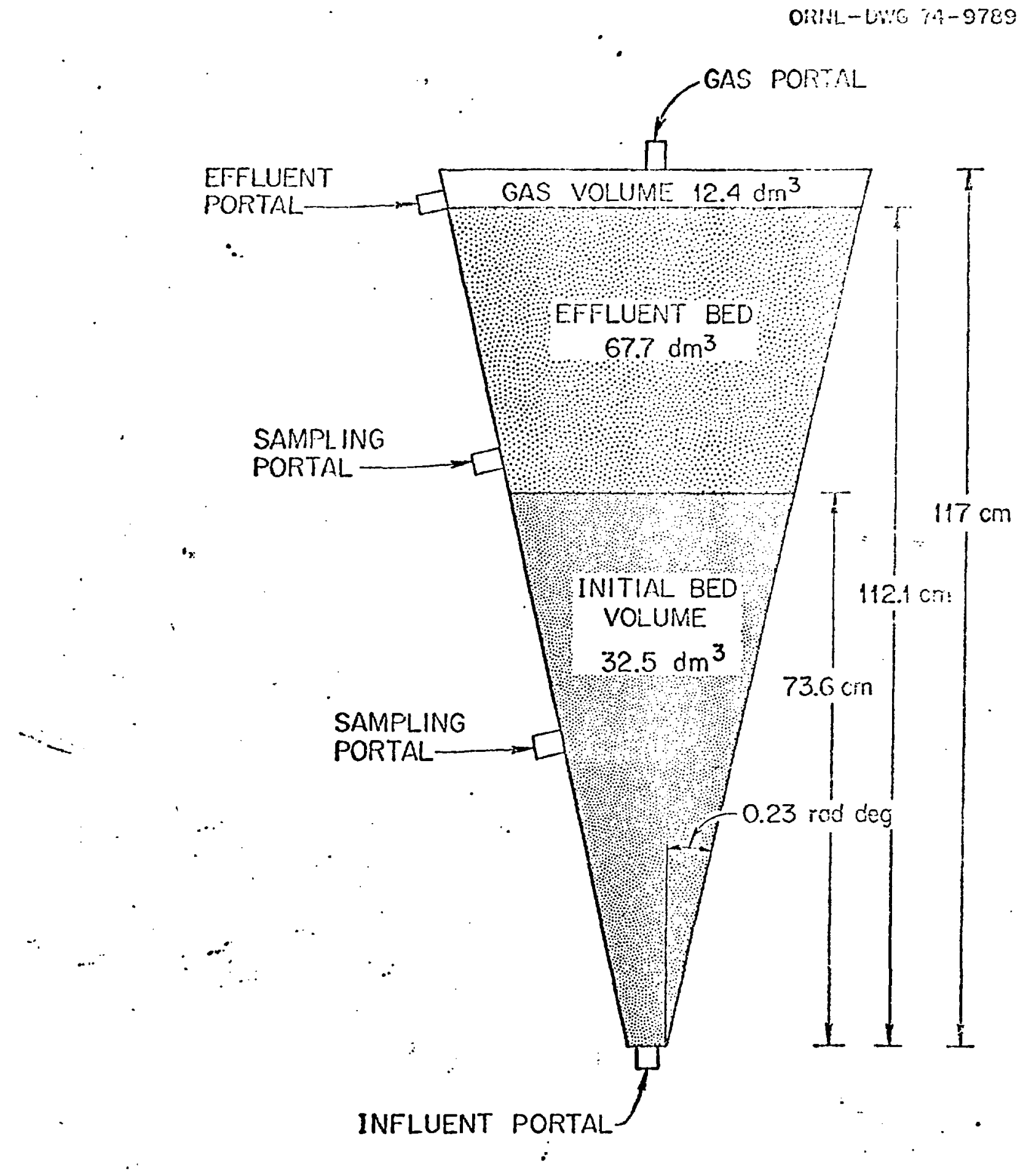

Fig. 1 


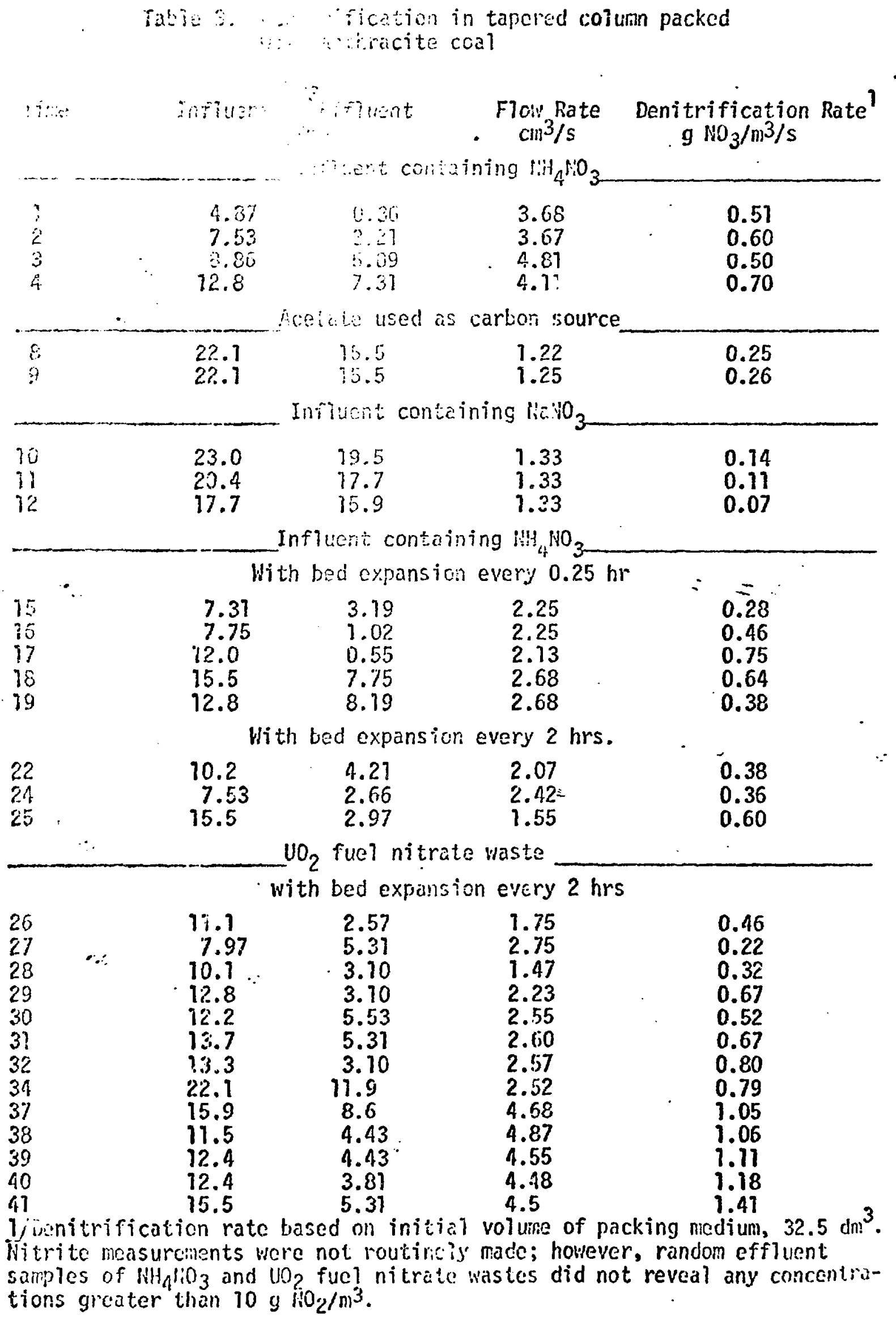




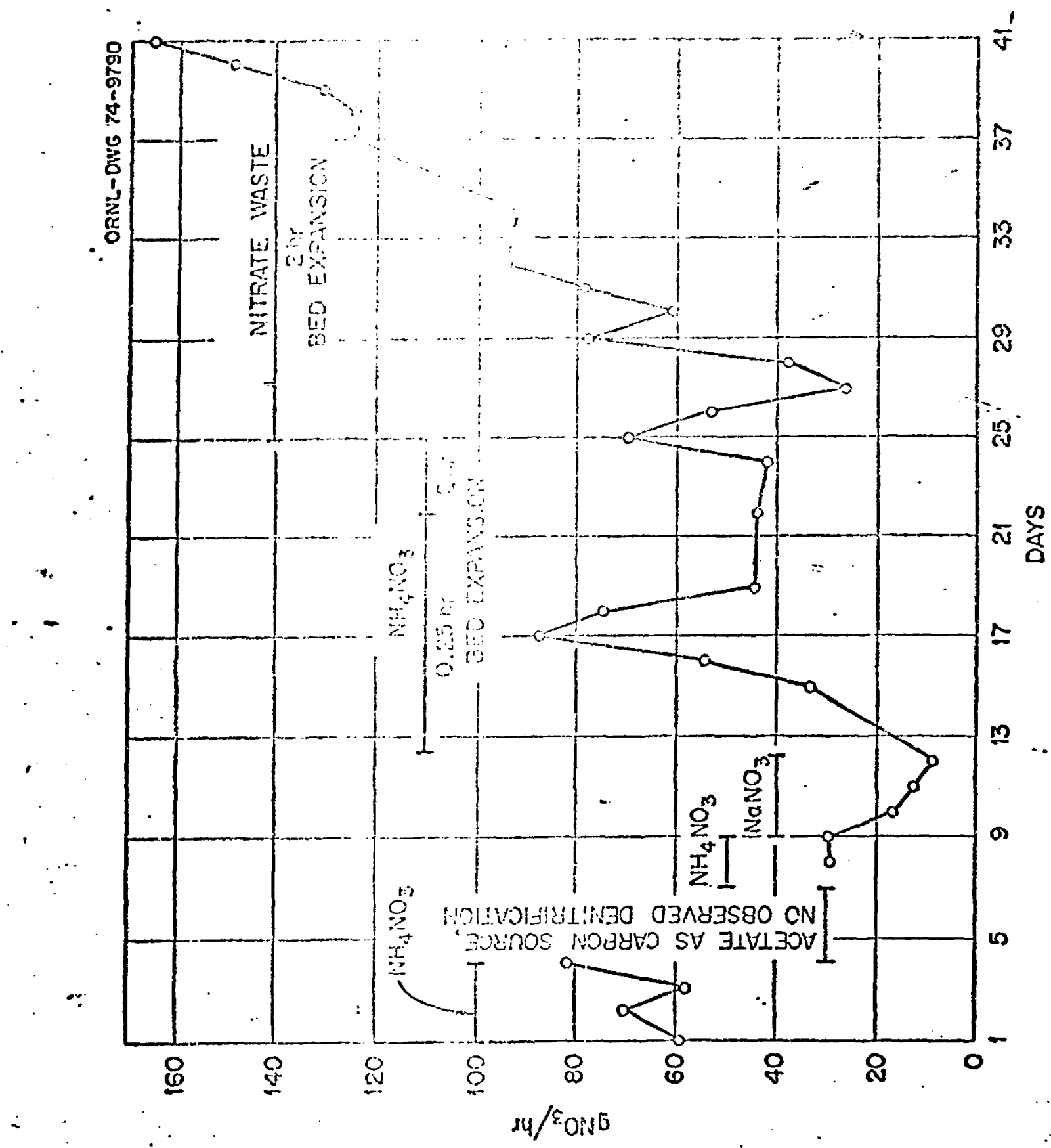


To avoid loss of the established microbial population, methanol was replaced as the carbon substrate. Nitrate analyses on the eighth and ninth day verified that denitrification had rusumed but at a much lower rate. However, the high influent nitrats concentrations may have been partially responsible for the low rates. Switching to $\mathrm{NaNO}_{3}$ as a nitrate source reduced the denitrification $75 \%$ after three days. The reduction was due either to continued exposure to nitrate concentrations $>15.0 \mathrm{~kg} \mathrm{NO} / 3 \mathrm{~m}^{3}$ or to some specific effect associated with $\mathrm{NaNO}_{3}$.

Taking into consideration the large quantities of nitrute detected in the $\mathrm{Na}^{\prime} \mathrm{O}_{3}$ effluents from the $120 \times 15 \mathrm{~cm}$ diameter columns, the reduction in denitrification rate was likely due to the inability of the ricroorganisms to accl imatize quickly to $\mathrm{NaNO}_{3}$. For example, a sinilar, but not as severe reduction in dentrification was noted on the substitution of $\mathrm{UO}_{2}$ fuel nitrate wastes (predominantly $\mathrm{NH}_{4} \mathrm{NO}_{3}$ and $\mathrm{HNO}_{3}$ neutralized to $\mathrm{pH} 6.4$ ) for $\mathrm{NH}_{4} \mathrm{NO}_{3}$ on the 26th and 27 th day. The difference between these nitrate sources was rather subtle, i.e., the ratio of nitrate to ammonium in the $\mathrm{UO}_{2}$ nitrate wastes was 5 to 1 rather than $1: 1$ as in $\mathrm{NH}_{4} \mathrm{NO}_{3}$ and the influent concentration of calcium after dilution with spring water was about $600 \mathrm{~g} / \mathrm{m}^{3}$ compared to $<20 \mathrm{~g} / \mathrm{m}^{3}$ for $\mathrm{NH}_{4} \mathrm{NO}_{3}$ influent. Even so, acclimatization for approximately three days was required before similar denitrification rates were attained.

Through the "Plexiglas" walls of the column, one could observe that a large number of pores in the anthracite bed were filled with gas rather than nitrate solution indicating that the packing material was not being 


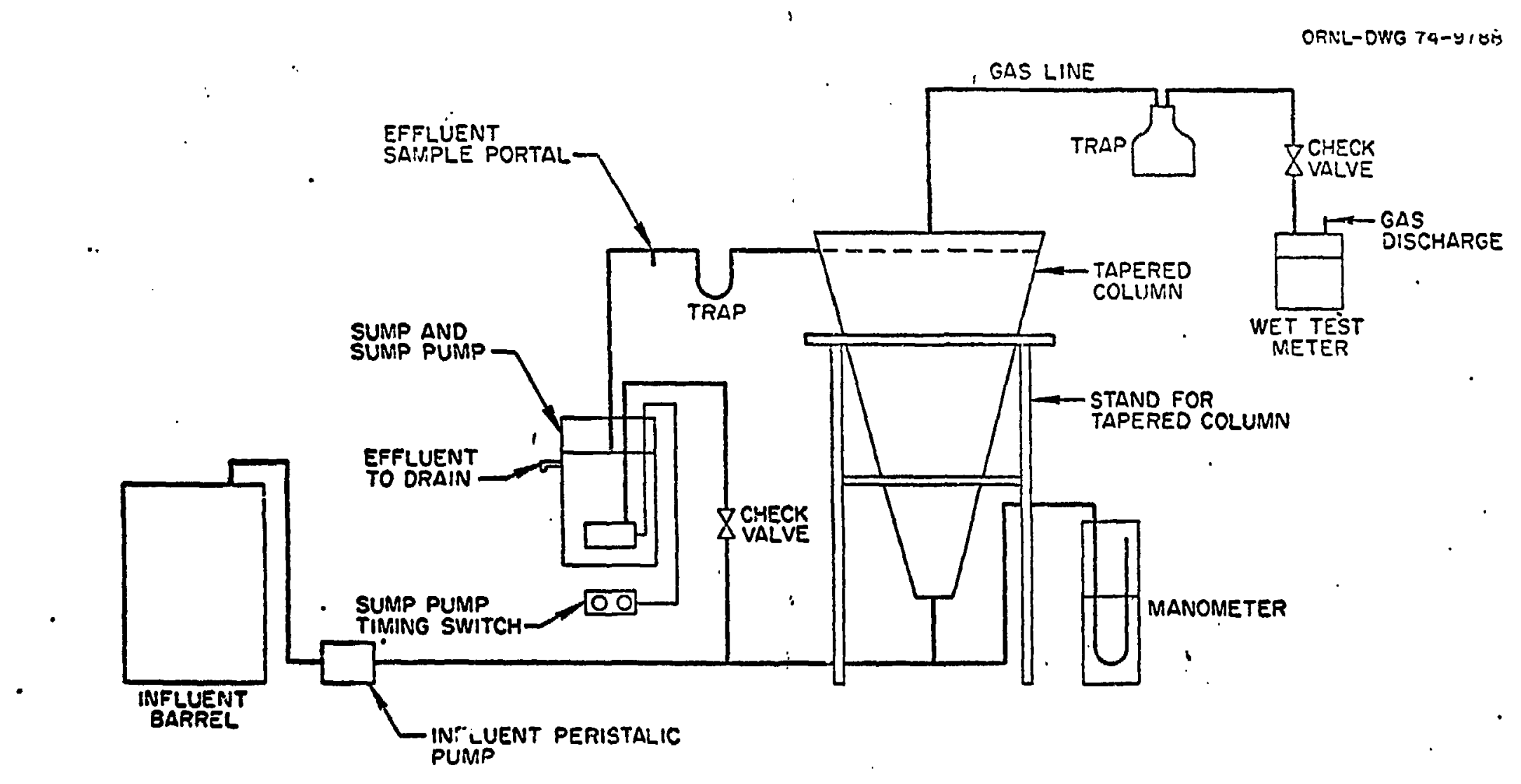

Fig. 3 


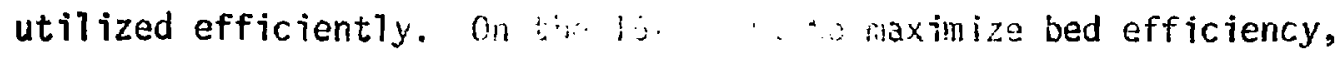
the bed was expandec by pul: rate $167 \mathrm{~cm}^{3} / \mathrm{s}$ ) of effluin: fic: . : : : : ery $0.25 \mathrm{hr}$. The manner in which this was condectoo $:$ : This procedure agitated the packing inedili: so $\ldots$.

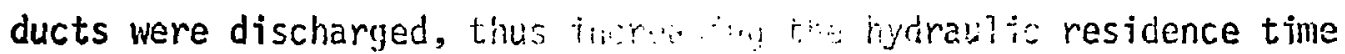
of fresh influent into the con: sion this fashion was carried out every 0.25 hr uniti i.: and a sharp decline in rate of doi: "ificion indicated that microorganisms were being washed ficili $: \cdots, \cdots)$ l:m; faster than they were being produced. On the 23rd day, bed exisich ms changed to every $2 \mathrm{hr}$. Gaseous discharge during bed oyja.. ion wis qute high; as great as $2 \mathrm{dm}^{3}$ or approximately $57 \mathrm{~cm}^{3} / \mathrm{s}$.

At the termination of the expinit, snitrification rates were established in excess of $\left.1 \mathrm{~g} \mathrm{NO}_{3} / \mathrm{M}^{3}, 3(\mathrm{Tab}) 3\right)$. These rates are 10-15 times higher than those reported in cintinious flow stirred reactors (Francis and Callahan, 1975).

Gaseous Discharge - The primary gasecul: products of denitrification are elemental nitrogen and cärbon diasida.

$$
5 \mathrm{CH}_{3} \mathrm{OH}+6 \mathrm{NO}_{3}^{-}+5 \mathrm{CO}_{2}+3 \mathrm{~N}_{2}+7 \mathrm{H}_{2} \mathrm{O}+60 \mathrm{H}
$$

The gaseous discharge from the tapered colulin packed with anthracite coal and fed with $\mathrm{UO}_{2}$ fuel fabrication wasles was approximately $92 \% \mathrm{~N}_{2}$ and $8 \% \mathrm{CO}_{2}$ (Table 4$)$. Considering thre stoichiometric ratio of $\mathrm{CO}_{2}$ to $\mathrm{N}_{2}$ from the above equation, the concentration of $\mathrm{CO}_{2}$ in the gaseous discharge was extremely low. However, the phi of the effluent was 
Table 4. Denitrification gas analyses from tapered column packed with antinracite coal

\begin{tabular}{|c|c|c|c|c|c|c|}
\hline \multicolumn{7}{|c|}{ Gas } \\
\hline Sample & $\overline{N_{2}}$ & $\mathrm{CO}_{2}$ & $\begin{array}{c}\mathrm{O}_{2} \\
\% \text { by volume }\end{array}$ & NO & Ar & MoOH \\
\hline 1 & 95.42 & 4.54 & 0.008 & 0.01 & 0.03 & 0.002 \\
\hline $\begin{array}{l}2 \\
3 \\
4 \\
5\end{array}$ & $\begin{array}{r}90.36 \\
90.63 \\
92.39 \\
92.24\end{array}$ & $\begin{array}{l}9.42 \\
9.01 \\
7.40 \\
7.58\end{array}$ & $\begin{array}{l}0.0084 \\
0.02 \\
0.07 \\
0.03\end{array}$ & $\begin{array}{l}0.02 \\
0.09 \\
0.008 \\
0.02\end{array}$ & $\begin{array}{l}0.06 \\
0.008 \\
0.02 \\
0.007\end{array}$ & $\begin{array}{l}0.09 \\
0.15 \\
0.06 \\
0.05\end{array}$ \\
\hline Average & 92.21 & 7.59 & 0.027 & 0.03 & 0.025 & 0.07 \\
\hline S.D. & 2.02 & 1.92 & 0.026 & 0.03 & 0.021 & 0.05 \\
\hline
\end{tabular}




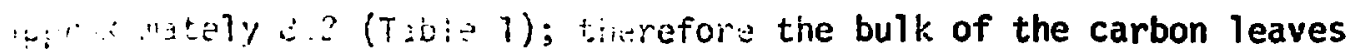

: : . . .

: - a d of acrebi: soli:- Values for mixed liquor volatile

...... in the effuchts ranged from 100 to $900 \mathrm{~g} / \mathrm{m}^{3}$.

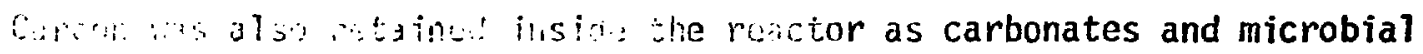

$\therefore \ddot{a}, \cdots n$.

Cation and then anthacite coal is used cor

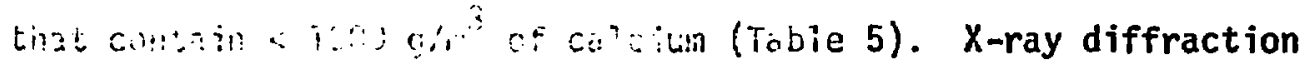

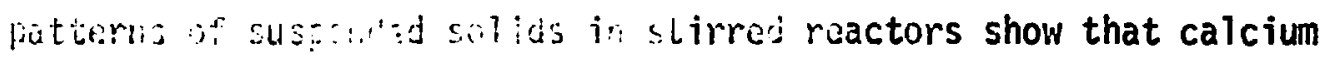
is preciptated as $\mathrm{CaCO}_{\mathrm{g}}$. Tho sine likaly holds true for columnar denitrification. Elem $\because$ othir than calcium were also removed, for cräple. phosphon, for wich ile mechenism. responsible rema in uncinar. Y-ray pitteris rharac'seristic of any calcium phosphates were noi detectes in tiv susporited solids from the stirred reactors. Quite likely, a relatichiship exisis similar to that of phosphorus adsorption in al al ine scils, i.e., phosphorus is either coprecipitated with or strongly cccluded to $\mathrm{CicO}_{3}$.

Trace Elemer: Retention - Heaction liechanisms governing the removal of the tralisition metals $\mathrm{Zn}, \mathrm{Hi}$, and $\mathrm{Cu}$ are unknown. Prolonged use of an anthracite bed for decitrification of influent streams containing appreciable quant: ties of these heavy metals will result in the accumulation of rather lirge quasititice of these metals. It is also difficult to predict what effect the builutg of the metals will have on subsequent denitrification. Further rescircis in this area is required. Cadnium, likely belayes like calciun because its ionic radius is nearly equal to 
that of calcium; it probably precipitates as $\mathrm{CdCO}_{3}$ or in mixtures of $\mathrm{CdCO}_{3} \cdot \mathrm{CaCO}_{3}$.

Denitrification columns packed with anthracite coal might be useful in uranium recovery operations. For example, $\mathrm{NH}_{4} \mathrm{NO}_{3}$ solution containing $5-10 \mathrm{~g} / \mathrm{m}^{3}$ of uranium was lowered to $<0.5 \mathrm{~g} / \mathrm{m}^{3}$ in one pass through a column packed with $11.12 \mathrm{dm}^{3}$ of anthracite coal. The uranitai likely coprecipitated on $\mathrm{Ca}$ and $\mathrm{Mg}$ carbonates or is convorted to an insoluble phosphate mineral similar to that of apatite, which is knokn to selectively concentrate uranium. The chemistry of Th and Pu indicates these elements would behave in a similar manner. Thus, columns of this type may be useful in removing low levels of plutonium from waste strcans containing nitrates.

Influence of Temperature - Denitrification is an exothermic reaction. The difference between influent $\left(295^{\circ} \mathrm{K}\right)$ and effluent temperature $\left(307^{\circ} \mathrm{K}\right)$ on the 39th day was 12 degrees. At a flow rate of $4.55 \mathrm{~cm}^{3} / \mathrm{s}$ and assuming for water a density of $3 \mathrm{~kg} / \mathrm{m}^{3}$ with a specific heat of $4.48 \mathrm{~J} / \mathrm{g} /{ }^{\circ} \mathrm{K}$, the rate of energy required to raise the influent to $307^{\circ} \mathrm{K}$ would be $228 \mathrm{~J} / \mathrm{s}$. Presumably, this heat is generated by the oxidation of $\mathrm{CH}_{3} \mathrm{OH}$. The quan-. tity of heat generated by the oxidation of $\mathrm{CH}_{3} \mathrm{OH}$ can be calculated in the following manner. The observed denitrification rate was $36.3 \mathrm{mg} \mathrm{HO}_{3} / \mathrm{s}$. Methanol analysis of the influent and effluent showed that $0.52 \mathrm{~g}$ of $\mathrm{CH}_{3} \mathrm{OH}$ was required to denitrify a gram of nitrate. Thus, the oxidation rate of $\mathrm{CH}_{3} \mathrm{OH}$ was $18.9 \mathrm{mg} \mathrm{CH} 3 \mathrm{OH} / \mathrm{s}$. If the heat of combustion for $\mathrm{CH}_{3} \mathrm{OH}$ is taken as $0.71 \mathrm{~mJ} / \mathrm{mol}$ then the rate of energy released on oxidizing is $422 \mathrm{~J} / \mathrm{s}$. Thus, the rate of heat generated is nearly twice that reflected by the increase in influent temperature. A portion of the remaining energy is 


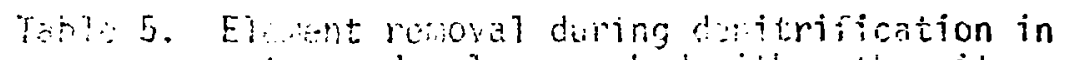
a whored colthin puched sith arthracite coal

\begin{tabular}{|c|c|c|c|}
\hline Eloment & $\begin{array}{r}\text { onos } \\
\text { Intitan }\end{array}$ & $\begin{array}{l}\text { atich } \\
\text { Effluent } \\
\end{array}$ & $\begin{array}{c}\text { Removal } \\
\%\end{array}$ \\
\hline Calcium & $\begin{array}{l}6: 5 \\
608 \\
615\end{array}$ & $\begin{array}{l}7.0 \\
4.6 \\
5.7\end{array}$ & $\begin{array}{l}99 \\
99 \\
99\end{array}$ \\
\hline Phosplicrus & $\begin{array}{l}3.0 \\
5.7 \\
7.7\end{array}$ & $\begin{array}{l}1.3 \\
0.52 \\
1.2\end{array}$ & $\begin{array}{l}5 \% \\
90 \\
83\end{array}$ \\
\hline Zinc & 0.75 & $<0.005$ & $>96$ \\
\hline Nickel & 0.30 & $<0.1$ & $>66$ \\
\hline Copper & 0.20 & 0.035 & $\therefore 82$ \\
\hline Cadmi um & 0.06 & $<0.005$ & $>91$ \\
\hline
\end{tabular}

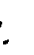

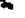


used for microbial growth while the remainder is lost as heat to the surrounding environment.

A large unit, one capable of denitrifying 5 inetric tons of nitrate daily and operating at this efficiency will generate considerable energy $58.1 \mathrm{GJ}$, which is equivalent to $54.6 \times 10^{6}$ BTU. Quite likely the heat loss in a larger unit will be much less which means the heat generated may 1 imit (up to a certain temperature may increase) the rate of denitrification. It appears that some type of cooling of larger units will be necessary if they are to operate at maximum efficiency.

\section{Polypropylene Raschig Rings}

Microbial populations were established faster on polypropylene rings than on the anthracite coal packing, viz., $<2$ weeks on rings compared to 3-4 weeks on the coal. Maximum denitrification rates (Table 6) based on initial bed size were similar $\left(1.0-1.2 \mathrm{~g} \mathrm{NO}_{3} / \mathrm{m}^{3} / \mathrm{s}\right)$. However, on prolonged operation ( $>40$ days) denitrification rates began to decrease to $0.3-0.7 \mathrm{~g} \mathrm{NO}_{3} / \mathrm{m}^{3} / \mathrm{s}$ after 50-60 days (Table 6). The reduction in denitrification rates was attributed to hydraulic short circuiting in the column due to excessive microbial growth. For instance, after 30-35 days, areas of dark colored microorganisms were observed in the lower portion of the column. Heal thy denitrifiers are pink colored, and they rapidly turn black if they do not receive a sufficient supply of nitrate. Initially, the dirk colored organism were suspected to be sulfate reducing microorganisms even though no evidence of $\mathrm{H}_{2} \mathrm{~S}$ could be detected. Sulfate concentration in the influent was reduced by a factor of 10 but the dark colored areas continued to grow. On the 45th day the column was flushed for 0.33 
used for microbial growth while the remainder is lost as hicat to tie surrounding environment.

A large unit, one capable of denitrifying 5 metric twis of nitrate daily and operating at this efficiency will generate considerable courgy $58.1 \mathrm{GJ}$, which is equivalent to $54.6 \times 10^{6}$ BTU. Quite lithely the hat loss in a larger unit will be much less which means the besi gener.ted may 1 imit (up to a certain temperature may increase) the sute of caitrification. It appears that some type of cooling of large: units will be necessary if they are to operate at maximum efficiency.

\section{Polypropylene Raschig Rings}

Microbial populations were established faster on polypiopylerie rings than on the anthracite coal packing, viz., $<2$ weeks on rings compared to 3-4 weeks on the coal. Maximum denitrification rates (Table 6) based on initial bed size were similar $\left(1.0-1.2 \mathrm{~g} \mathrm{NO}_{3} / \mathrm{mi}^{3} / \mathrm{s}\right)$. However, on prolonged operation ( $>40$ days) denitrification rates began to decrease to $0.3-0.7 \mathrm{~g} \mathrm{~N}_{3} / \mathrm{m}^{3} / \mathrm{s}$ after 50-60 days (Table 6). The reduction in denitrification rates was attributed to hydraulic short circuiting in the column due to excessive microbial growth. For instance, after 30-35 days, areas of dark colored microarganisms were observed in the lower portion of the column. Healthy denitrifiers are pink colored, and they rapidly turn black if they do not receive a sufficient supply of nitrate. Initially, the dark colored organism were suspected to be sulfate reducing microorganisms even though no evidence of $\mathrm{H}_{2} \mathrm{~S}$ could be detected. Sulfate concentration in the influent was reduced by a factor of 10 but the dark colored areas continued to grow. On the 45 th day the column was flushed for 0.33 
Table 6. Denitrification in a column packed with $1.6 \mathrm{~cm}$ dia. polypropylene raschig rings

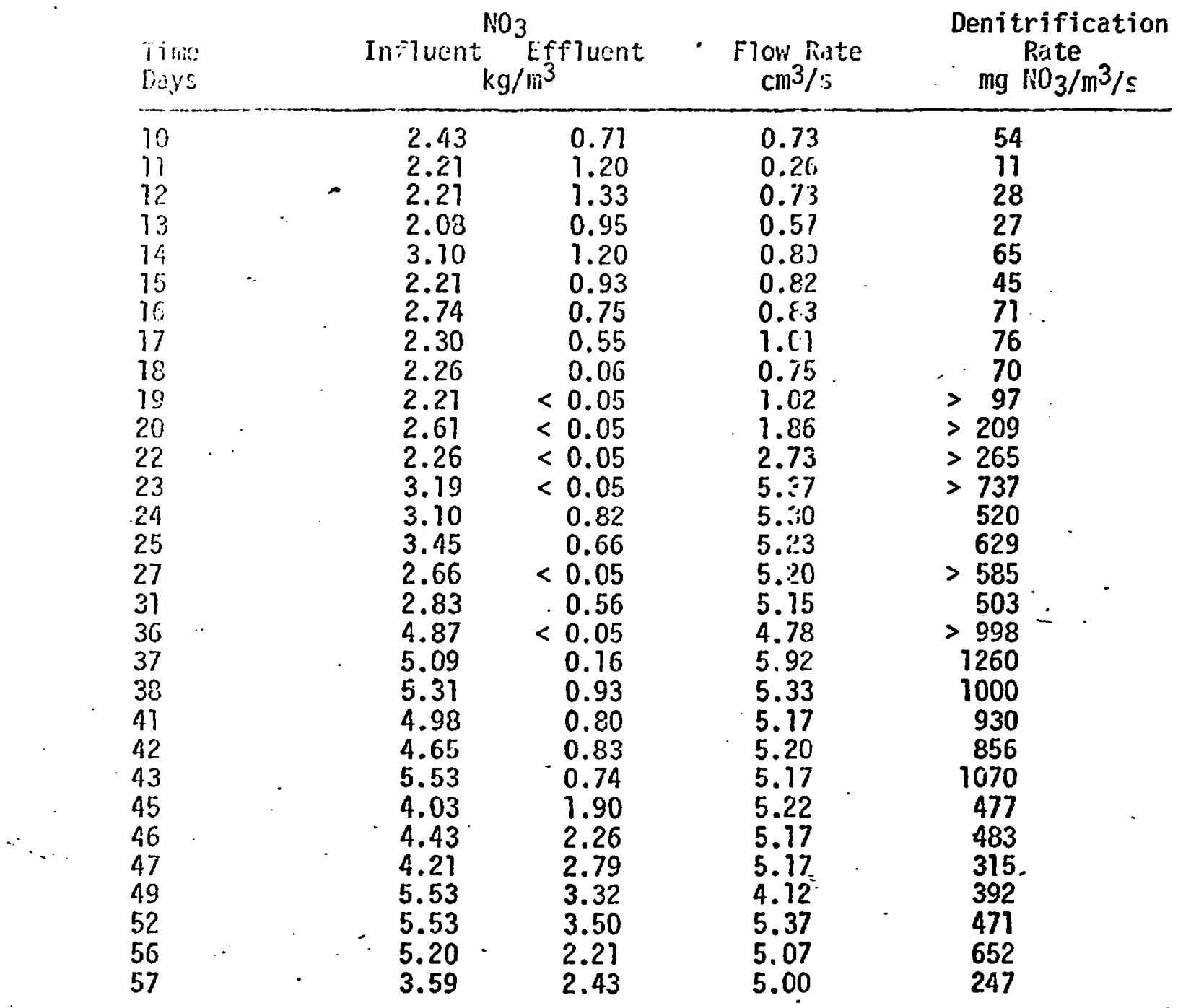

1/ Denitrification rate based on initial bed volume, $23.2 \mathrm{dm}^{3}$. . 
hr at a flow rate of $115 \mathrm{~cm}^{3} / \mathrm{s}$. Visual observation of the effluent or microbial mass in the column indicated that little bicmass nad bech removed and denitrification rates the following 10 days were not appreciably changed. At the end of the experiment, laixed i iguor suspended solids, MLSS, were $28.7,37.6$ and $83.0 \mathrm{~kg} / \mathrm{m}^{3}$ at the top, center and bottom of the column, respectively. These MLSS values are significantly higher than the maximum IALSS values of $5.55 \mathrm{~kg} / \mathrm{m}^{3}$ observed in stirred reactors fed $\mathrm{NH}_{4} \mathrm{NO}_{3}$ (Francis and Malone 1975a). With the $1.6 \mathrm{~cm}$ diameter polypropylene ring, microbial growth fills the center of the ring and reduces the sirface area exposed to nitrate solution. Possibly, larger diameter rings would be more effective for long term use.

\section{DENITRIFICATION KINETICS}

A number of investigators (Requa and Schroeder 1973; Moore and ichroeder 1971; Sterise1, Loehr, and Lawrence 1973) have evaluated the kinetics of denitrification at low nitrate substrate concentrations i $250 \mathrm{~g} \mathrm{NO}_{3} / \mathrm{m}^{3}$ ) and have conciuded that as long as there is a sufficient supply of a carbon substrate the rate of denitrification does not decrease until the nitrate concentration approaches $<0.05 \mathrm{~g}$ $\mathrm{NO}_{3} / \mathrm{m}^{3}$. To our knowledge, no one has evaluated denitrification kinetics at nitrats substrate concentrations $>1000 \mathrm{~g} \mathrm{NO}_{3} / \mathrm{m}^{3}$. The major purpose in evaluating denitrification kinetic data is that it can be used to determine nitrate concentrations for optinum dentrification rates.

Proper evaluation of denitrification kinetics in columnar studies is difficult because the concentration of substrate nitrate in an upward 
flow column will decrease with increasing column height. In addition, denitrification rates in this study vere based on the volume of initial

- packing media rather than current hydraulic residence times and microbial concentrations. Thus, any treatment of denitrification kinetics here should be viewed as a tool to evaluate the influence of nitrate substrate concentrations on rates of denitrification and not as establishing maximum specific substrate removal rates per unit weight of microorganism or a specific value for the Michaelis-Menten constant such as described by Monod (1949). A more formal treatment of denitrification kinetics is presented in the continuous flow stirred reactor work (Francis and Malone 1975a).

If an active microbial-nitrate compound (MS) is formed in the reaction between a microbial enzyme $(M)$ and a specific nitrate concentration (s) at equilibrium, the reaction may be represented as

$$
K_{S}=(M)(S) /(M S)
$$

where $k_{s}=$ the dissociation constant. Thus, only at low nitrate concentrations is the denitrification rate proportional to nitrate concentrations. If the observed denitrification rates $(R)$ are expressed in terms of the Mechael is and Menten equation, then

$$
R=R_{\max }(s) /\left[K_{s}+(s)\right]
$$

where $R_{\max }$ is the maximum denitrification rate obtained only when all the microbial enzyme (M) is combined in the form (MS) and $K_{s}$ is equal 
to the nitrate concentration at $1 / 2 R_{\max } \cdot R_{\max }$ and $K_{s}$ can be solved graphically by plotting the Lineweaver and Burk equation, that is

$$
(s) / R=(s) / R_{\max }+K_{s} / R_{\max } \cdot
$$

The Lineweaver-Burk equation is formed by taking the reciprocal of both sides of Eq. 2 and multiplying the equation through by (S). Thus, $R_{\max }$ and $K_{s}$ can be graphically solved by plotting $(s) / R$ on the 1 inear ordinate verses ( $S$ ) on the abscissa; the intercept is $K_{S} / R_{\max }$ and the constant slope is : $/ R_{\max }$. This form is more appropriate for $R_{\max }$ and $\mathrm{K}_{\mathrm{s}}$ determinations at high substrate concentrations (Lineweaver and Burk 1934) and has been used to determine values of $K_{s}$ and $R_{\max }$ at nitrate substrate concentrations $\left(<5 \mathrm{~g} \mathrm{NO}_{3} / \mathrm{m}^{3}\right.$ ) by Requa and Schroeder 1973. Nitrate concentrations on the order of $5 \mathrm{~g} \mathrm{NO}_{3} / \mathrm{m}^{3}$ are very low relative to nitrate conceritrations used in our work; however, $5 \mathrm{~g} \mathrm{NO}_{3} / \mathrm{m}^{3}$ is high relative to concentrations which 1 imit rates of denitrification, i.e., $<0.05 \mathrm{~g} \mathrm{NO}_{3} / \mathrm{m}^{3}$.

To test if $R_{\max }$ and $K_{s}$ could be evaluated, effluent nitrate concentrations were treated as substrate concentrations. If denitrification mechanisms follow the Michaelis and Menten equation, a straight line should result on flotting $(S) / R$ verses $(S)$. With $\mathrm{NH}_{4} \mathrm{NO}_{3}$ as effluent concentrations < $; 000 \mathrm{~g} \mathrm{NO}_{3} / \mathrm{m}^{3}$ (Fig. 4), the linear regression analyses $(r=0.948)$ resulted in values for $R_{\max }$ and $\mathrm{K}_{\mathrm{s}}$ of $351 \mathrm{mg} \mathrm{NO}{ }_{3} / \mathrm{m}^{3}$ and $3.86 \mathrm{~g} \mathrm{NO}_{3} / \mathrm{m}^{3}$, respectively. The value for $K_{s}$ is slightly 10 times larger than $0.35 / 9 \mathrm{NO}_{3} / \mathrm{m}^{3}$ determined by Reqa and Schroeder (1973) at substrate nitrate concentrations $<5 \mathrm{~g} \mathrm{NO}_{3} / \mathrm{m}^{3}$. Considering the error involved in such a determination where substrate concentrations range 
from 100 to 1000 times higher than those used by Rega and Scliroeder, $3.86 \mathrm{~g} \mathrm{NO}_{3} / \mathrm{m}^{3}$ is probably not a bad estimatc. At nitrate substrate concentrations $>1000 \mathrm{~g} \mathrm{NO}_{3} / \mathrm{mt}^{3}$ the curve tecomes concave upward (Fig. 5), implying reaction mechanisus different than the simple reaction, $M+S \neq M S$. Further detailed analyses of the kinetic data are necessary to determine what mechanisms maz, sut not necessarily, hold.

The upward curvature of the curve in Fig. I represents the formation of an inactive enzyme-substrate (Lineveaver and Burk 1934) formed because of excessive substrate, viz., the reaction is substrate inhibited at high nitrate concertraticns. Using the methods presented by Lineweaver and Burk for substrate inhibition, the relative concentrations of free, active, and inactive enzyne forms are calculated at various substrate nitrite concentrations (Fig. 6). As effluent nitrate concentrations exceed $5 \mathrm{~kg} \mathrm{HO}_{3} / \mathrm{m}^{3}$ the inactive enzyme form rapidly increases. For example, at $10 \mathrm{~kg}$ $\mathrm{NO}_{3} / \mathrm{m}^{3}<40 \%$ of the enzyme is in the active fcrm. The accuracy of such calculations is difficult to validate. The important conclusions from these kinetic calculations are that nitrate at excessively high substrate concentrations apparently inhibit the rate of denitrification and maximum denitrification per reactor volume can be achieved by increasing flow rates and keeping influent $n$ : trate concentrations $<6.5 \mathrm{~kg} \mathrm{NO} 3 \mathrm{~kg} / \mathrm{m}^{3}$ (assuming constant microbial concentration is maintained).

Other factors such as $\mathrm{CH}_{3} \mathrm{OH}$ and aunnonium concentrations may also be responsible for observed inhibition and should not be 


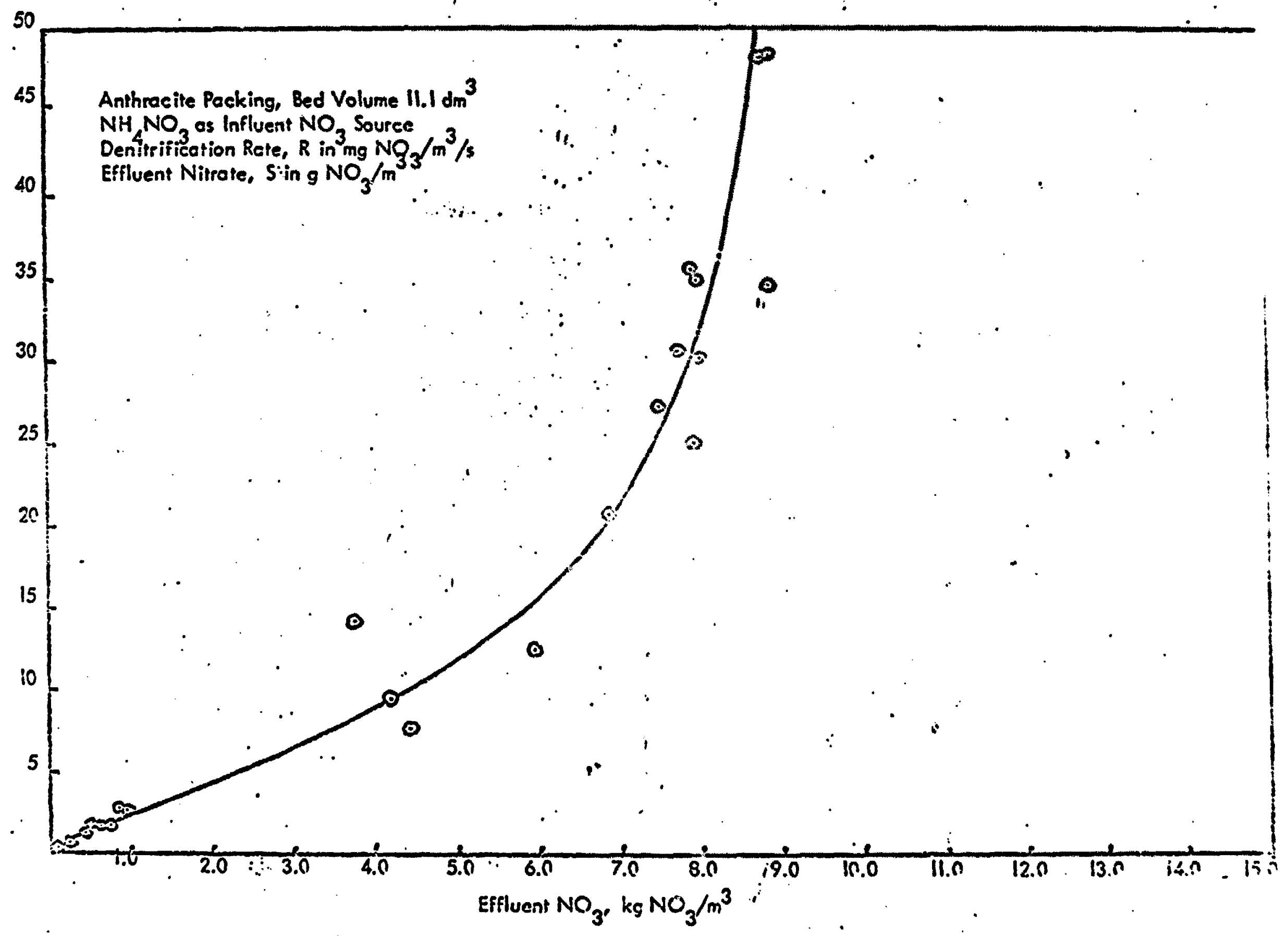




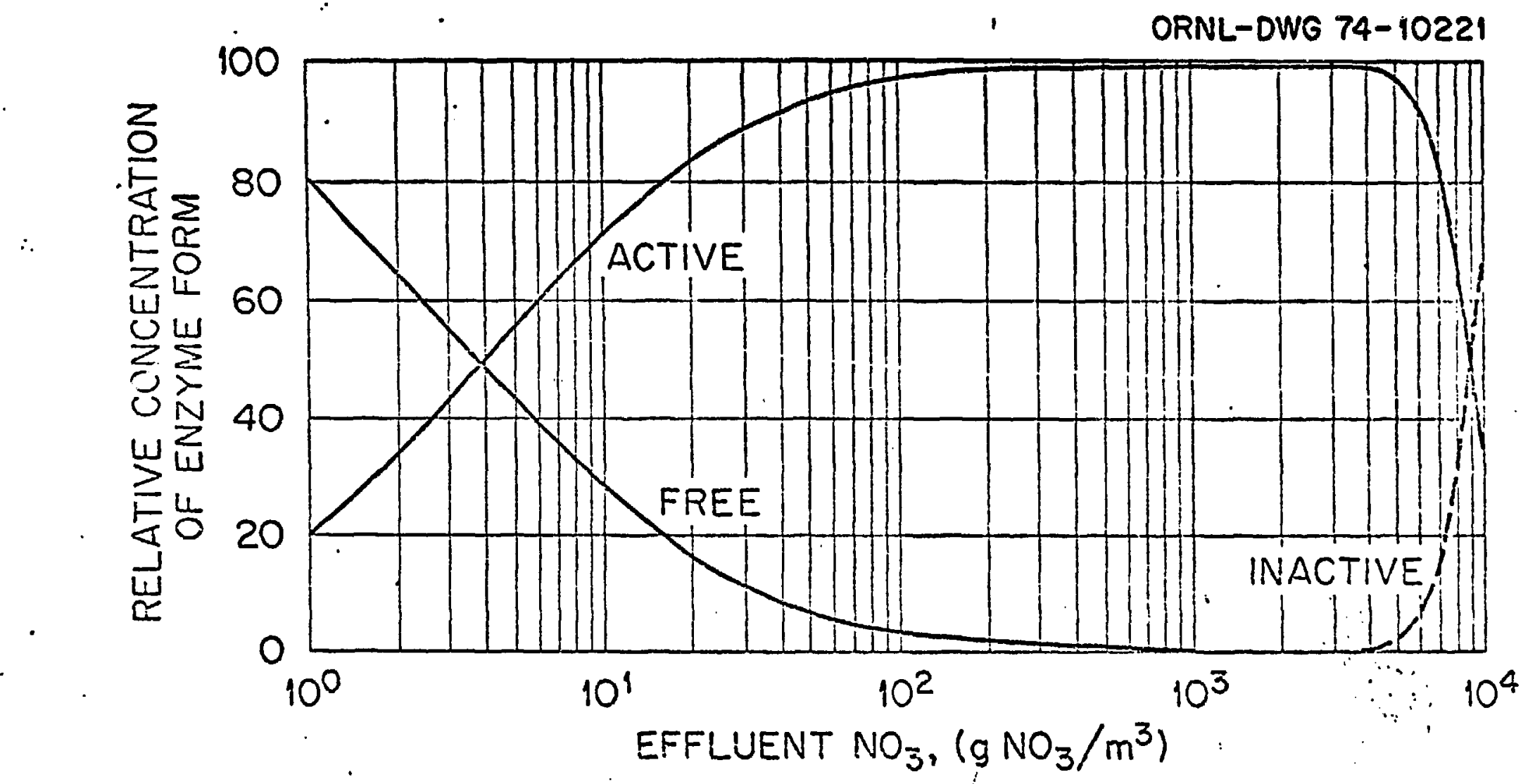

Fig. 6 
entirely discomte : How concentrations as his as $10 \mathrm{~kg} / \mathrm{m}^{3}$ did not inhibit denitrification - rates (Francis and $\therefore$ iche $19 / 5 i$ ). The influence of ammonium has not been fully evaluatud.

Other factors such as riysical alterations that take place in the anthracite bed sion?d be considered as variables that might cause responsss simila: Lu that illustrated in Fig. 5. One alteration is the influence of incercising denitrification rates on the mean hydraulic residence time in th: anthracite bed. For example, as denitrification increases, the genorition of $\|_{2}$ increases, which may decrease the residence time of 11 itrate substrate; flow-rate is unchanged. Thus, for the same amourt ni nitrote denitrified, as the residence time decreases $R$ increass; and $(S) / R$ decreases which is opposite to the response observed in Fig. 5 .

Another factor that should be considered is heat. Influent temperature was mintiined at $301^{\circ} \mathrm{K}$. Effluent temperature was not recorded in the kinetic studies; however, earlier work in the same column with a themocouple located in the middle of the bed, temperatures were rocoided from $304-310^{\circ} \mathrm{K}$ when influent temperatures ranged between $293-295^{\circ} \mathrm{K}$. Effluent temperatures as high as $307^{\circ} \mathrm{K}$ were recorded in a tapered column packed with $32.5 \mathrm{dm}^{3}$ of anthracite. Heat inhibition would result in a response similar to that illustrated in Fig. 5.

Kinetics of denitrification were evaluated in a similar manner. in continuous flow stirred reactors using influents containing $\mathrm{NH}_{4} \mathrm{NO}_{3}$ (Francis and Malone 1975a). In this case denitrification 
rates were expressed in terms of specific renoval rates (U) detcrmined by the difference between influert and effluent nitrate concentrations at current hydraulic residence times and mixed liguor volatile suspended solids (MLUSS). Lineweaver-Burk plots at nitrate substrate concentrations $<6 \mathrm{~kg} \mathrm{NO} / \mathrm{m}^{3}$ resulted in a very high linear regression coefficient $(r=0.997)$ and a maximum specific removal rate $\left(u_{\max }\right)$ of $1.97 \times 10^{-5} \mathrm{~s}^{-1}$, a value very close to $1.59 \times 10^{-5} \mathrm{~s}^{-1}$ reported by Moore and Schroeder (1971) in continuous flow stirred reactors. At nitrate substrate concentrations 6 to $10 \mathrm{~kg} \mathrm{NO} / \mathrm{N}^{3}$ denitrification rates appeared to be substrate inhibited. The relative concentrations of free, active and inactive enzyme forms were calculated according to Lineweaver and Burk as in the case of the columnar denitrification data. In both cases, columnar and continuous flow stirred reactor studies, approximately $50 \%$ of the microbial-enzyme population was calculated to be in the inactive form at substrate nitrate concentrations between 9 and $10 \mathrm{~kg} \mathrm{NO} / \mathrm{m}^{3}$. Recent work using influents containing $\mathrm{Ca}\left(\mathrm{NO}_{3}\right)_{2}$ in continuous flow stirred reactors also show that at concentrations $>7 \mathrm{~kg} \mathrm{NO}_{3} / \mathrm{m}^{3}$ the rate of denitrification rapidly decreases.

\section{METHANOL UTILIZATION}

Numerous denitrification studies at low nitrate concentrations ( $<250 \mathrm{~g} \mathrm{NO}_{3} / \mathrm{m}^{3}$ ) have shown that $0.6 \mathrm{~g}$ of methanol is required to denitrify one gram of nitrate (McCarty et al. 1969; Smith et al. 1972). This work at high nitrate concentrations (> $1000 \mathrm{~g} \mathrm{NO}_{3} / \mathrm{m}^{3}$ ) indicates that less $\mathrm{CH}_{3} \mathrm{OH}$ is required (Table 7). The stoichiometric $\mathrm{CH}_{3} \mathrm{OH}$ requirement to denitrify one gram of nitrate is $0.43 \mathrm{~g}$ 
Table \% Denitrificition rethanol reguirements

\begin{tabular}{cc}
$\mathrm{Cil}_{3} \mathrm{OIl}$ & Sample \\
Mtilization & Nunter \\
\hline
\end{tabular}

Colunnar Denitrifiation

Anthracite pacising

Anthracite pacting in tapered colum:

Polspropylene kazchig rings

$0.185+0.35^{2}$

$0.45 \mp 0.14$

18

$0.29 \pm 0.14$

16

14

1) Grans of $\mathrm{CH}_{3} \mathrm{OH}$ required to denitrify grate of nitrate

2) Standard deviativil 
$\mathrm{CH}_{3} \mathrm{OH}$; however, it does not provide sufficient carbon for microbial growth or deoxygenation of any dissolved oxygen present in the system.

The $\mathrm{CH}_{3} \mathrm{OH}$ requirement for denitrification wi:h polypropylene Raschig ring packing appears to be approximately $50 \%$ lower than with anthracite packing (Table 7 ). In the case where $1.6 \mathrm{~cm}$ dianieter polypropylene rings were used for packing, exces;ive microbial growth caused hydraulic short circuiting in the column which resulted in appreciably lower denitrification rates after operation of the unit in excess of 40 days. The $\mathrm{CH}_{3} \mathrm{OH}$ utilization constant observed with the polypropylene rings was below the stoichiometric $\mathrm{CH}_{3} \mathrm{OH}$ requirement for denitrification, indicatirg that the microbial biomass (maximum of $83 \mathrm{~kg} \mathrm{MLSS} / \mathrm{m}^{3}$ at the bisttom of the column) was being utilized as an endogeneous carbon source. The $\mathrm{CH}_{3} \mathrm{OH}$ requirement decreased in proportion to the length of operation (Fig. 7).

It appears that denitrification at high nitrate concentrations requires approximately 25\% less $\mathrm{CH}_{3} \mathrm{OH}$ than deritrification at low nitrate substrate concentrations. For example, the work of McCarty et al. 1969 and Smith et al. 1972 where nitrate substrate concentrations were in the order of $5-10 \mathrm{~g} \mathrm{NO} / \mathrm{m}^{3}$ required $0.6 \mathrm{~g}$ of $\mathrm{CH}_{3} \mathrm{OH} / \mathrm{g}$ of $\mathrm{NO}_{3}$ while, in our work, where nitrate substrate concentrations were on the order of 500 to $5000 \mathrm{~g} \mathrm{NO}_{3} / \mathrm{m}^{3}$ the $\mathrm{CH}_{3} \mathrm{OH}$ requirement for each $\mathrm{g}$ of nitrate was on the order of 0.4 to $0.5 \mathrm{~g}$. This may be a result of two possible relationships. One, in the denitrification at high nitrate concentrations higher microbial buildup occurred in the reactors than at low nitrate concentrations and a portion of the carbon 
requirement was due to an endogeneous carbon source ritier tian added $\mathrm{CH}_{3} \mathrm{OH}$. Two, at high nitrate substrate concentration: (500 to 5000 g $\mathrm{NO}_{3} / \mathrm{m}^{3}$ ) a greater proportion of the microbial-enzyli: for ${ }^{\prime} \mathrm{s}$ in the active form than at nitrate substrate concentrations $=10 \quad 5: 0_{3} / \mathrm{m}^{3}$ (Fig. 6). Thus, at low nitrate concentrations $\mathrm{Ct}_{3} \mathrm{OH}$ me st be : ilized to support both a free and active form (approxinately $50 \%$ ecch at $5 \mathrm{~g} \mathrm{NO}_{3} / \mathrm{m}^{3}$, Fig. 6) while at nitrate substrate concentrations between 500 and $5000 \mathrm{~g} / \mathrm{m}^{3}$ the enzyme form is $>95 \%$ in the active form.

\section{SUMMARY AND CONCLUSIONS}

Anaerobic columns packed with anthracite ccal particles appear to be an effective method for the treatment of nitrate wastes associated with uranium recovery operations which use the am:anium diuranate process. This process is used in mary of tine prescitily operated $\mathrm{UO}_{2}$ fuel fabrication plants and will be used in future fuel reprocessing facilities. Nitrate wastes generated in this process are predominantly nitric acid and $\mathrm{NH}_{4} \mathrm{NO}_{3}$. The quantity of nitrates in the waste streams from these facilities are expected to be as high as 5 metric tons of nitrate a day.

Using the denitrification rate of $1 \mathrm{~g} \mathrm{NO}_{3} / \mathrm{mi}^{3} / \mathrm{s}$ (Table 3 ), tiie rate for one day would be $86.4 \mathrm{~kg} \mathrm{NO}_{3} / \mathrm{m}^{3} /$ day. "ihus, to denitrify 5 metric tons of nitrate a day $\left(5 \times 10^{6} \mathrm{~g} \mathrm{NO}_{3}\right)$ vould require a bed volume of $57.9 \mathrm{~m}^{3}$. For a bed $8 \mathrm{~m}$ in diameter the required height would be slightly over one meter $(1.2 \mathrm{~m})$.

Denitrification kinetic data indicate that the most effective influent concentrations range between 500 and $5 \times 10^{3} \mathrm{~g} \mathrm{NO}_{3} / \mathrm{n}^{3}$. If 
$5 \mathrm{~kg} \mathrm{NO}{ }_{3} / \mathrm{m}^{3}$ is selected as the influent concentration the required volume for 5 metric tons of nitrate a day would be $10^{3} \mathrm{~m}^{3}$ or a flow rate of $11.6 \mathrm{dm}^{3} / \mathrm{s}$. The cross-sectional flow into a $1.2 \times 8 \mathrm{~m}$ diameter column would be $0.23 \mathrm{dm}^{3} / \mathrm{m}^{2} / \mathrm{s}$, about 10 fold less than that in the tapered column used in these studies. Mechanical stirrers could be used to maintain bed integrity or the bed could be fluidized in a tapered column by using anthracite of smaller particle size. A recycle system could be used if $\mathrm{pH}$ levels and ammonium concentrations could be maintaine. 1 at nontoxic conditions.

Extrapolations of laboratory bench experiments to production size facilities are often haphazardous and speculative. However, data presented in this paper certainly justify pilot plant tests at faciities where the disposal of large quantities of nitrate wastes are a protlem. 
LITERATURE CITED

1. Auerbach, S. I. et a1. 1974. Biological denitrification of highnitrate wastes. pp. 13-14. IN Environment;a1 Sciences Division Annual Report. ORNL-4935, Oak Ridge National Laboratory, Oak Ridge, Tennessee.

2. Bremner, J. M. 1965. Nitrite by colorimetric methods. pp. 12191224. IN C. A. Block (ed.), Methods of Soil Analysis - Part 2, Chemical and Microbiological Properties. American Society of Agronomy, Madison, Wisconsin.

3. Francis, C. W. and M. W. Callahan. 1975. Biological denitrification and its application in the treatment of high nitrate wastewaters. J. Environ. Qual. (In press).

4. Francis, C. W. and C. D. Malone. 1975a. Denitrification of nitrate concentrations $>1000 \mathrm{ppm} \mathrm{NO}_{3}$ in continuous flow stirred reactors. To be submitted to Water Res.

5. Francis, C. W. and C. D. Malone. 1975b. Vitrate measurenents using a specific ion electrode in presence of nitrite. Soil Sci. Soc. Am. Proc. (In press).

6. Johnson, W. K. and G. J. Schroepfer. 1964. Nitrogen removal by nitrification and denitrification. J. Water Pollut. Contr. Fed. 86(8): 1015-1036.

7. Lineweaver, H. and D. Burk. 1934. Determination of enzyine dissociation constants. J. Am. Chem. Soc. 56: 658-667.

8. HcCarty, P. L. 1969. Feasibility of the denitrification process for removal of nitrate-nitrogen from agricul tural drainage waters. Appendix to Cal ifornia Department of Water Resources Bulletin 1743 . 
9. Monod, 3. 1949. The growth of bacteria sultures. Ann. Rev. Microbal. 3: $371-394$.

10. Moore, S. F. and E. D. Schroeder. 1971. The effect of nitrate feed rate on denitrification. Water Res. 5: 445-452.

11. Reqa, D. A. and E. D. Schroeder. 1973. Kinetics of packed-bed denitrification. J. Water Pollut. Contr. Fed. 45: 16961707.

12. Smith, J. M., A. N. Masse, W. A. Feige, and L. J. Kamphake. 1972. Nitrogen removal from municipal waste water by columnar denitrification. Environ. Sci. Tech. 6(3): 260-267.

13. Stensel, H. D., R. C. Loehr, and A. W. Lawrence. 1973. Biological kinetics of suspended-growth denitrification. $J$. Water Pollut. Contr. Fed. 45(2): 249-261. 


\section{Figure Legends}

Fig. 1. Tapered column dit ansion.

Fig. 2. Inflience of nitiate and carber source, hed expansion and time on denitrification in a tapered columa.

Fig. 3. Schenatic of the taperes coluiar denitrification system.

Fig. 4. Lineweaver-Burk plots of effiturit nitrate concentrations $<1000 \mathrm{~g} / \mathrm{n}_{1} 3$.

Fig. 5 Lineweaver-Burk piots of efflucitt nitrate concentration to $10 \mathrm{~kg} \mathrm{NO} / \mathrm{m}^{3}$.

Fig. 6. Relative concentration of enzyme form as influcnced by effluent nitratc concentriction.

Fig. 7. Influence of tilla on CH $\mathrm{OH}$ requirenents in a colurin packed with $1.6 \mathrm{~cm}$ dianter polypropylene raschig rings. 